\title{
INOVASI MEMEDIASI TQM DAN KINERJA PERUSAHAAN PADA SEKTOR UKM
}

\author{
INNOVATION MEDIATING TQM AND FIRM PERFORMANCE IN THE SMES SECTOR
}

\author{
Yolanda Masnita ${ }^{1 *)}$, Abdul Rahman²), Andhika Veraldy ${ }^{3)}$ \\ ${ }^{1,2,3)}$ Faculty of Economics and Business, Trisakti University, Jl. Kyai Tapa No. 1, Grogol, Jakarta 11440, Indonesia \\ Penulis Rekomendasi: yolandamasnita@yahoo.com
}

DOI Number : 10.30988/jmil.v3i2.138

\begin{abstract}
In strategy competition, innovation must be clear and precise in accordance with consumer demand and expectations. Limited organizational resources require organizations to manage innovation clearly. The company's efforts to change or increase product output, both from its processes and services, are interpreted as innovation. This study aims to examine the effect of total quality management on company performance with two approaches, additional innovation and radical innovation. The hypothesis was tested from data collected from 108 food and beverage SMEs registered at the Indonesian Food and Beverage Entrepreneurs Association - GAPMMI using convenience sampling data processed with AMOS. The results of the study show that additional innovation as a TQM mediator has an influence on company performance. In addition, testing shows that radical innovation has no effect on company performance. Therefore, additional innovation is the best way that SMEs can choose as a TQM approach to influence company performance. This research can contribute to small and medium enterprises in the selection of innovations in the practice of TQM. This will help entrepreneurs get better company performance
\end{abstract}

Key words: total quality management; incremental innovation; radical innovation; firm performance; SMEs

\begin{abstract}
Abstrak
Dalam kompetisi strategi, inovasi harus jelas dan tepat sesuai dengan permintaan dan harapan konsumen. Terbatasnya sumber daya organisasi menuntut organisasi mengelola inovasi dengan jelas. Upaya perusahaan untuk mengubah atau meningkatkan output produk, baik dari proses dan layanannya, ditafsirkan sebagai inovasi. Penelitian ini bertujuan untuk meneliti pengaruh manajemen kualitas total terhadap kinerja perusahaan dengan dua pendekatan, inovasi tambahan dan inovasi radikal. Hipotesis diuji dari data yang dikumpulkan dari 108 UKM makanan dan minuman yang terdaftar di Gabungan Pengusaha Makanan dan Minuman Indonesia - GAPMMI dengan menggunakan convenience sampling data diolah dengan AMOS. Hasil penelitian menunjukkan bahwa inovasi tambahan sebagai mediator TQM, memiliki pengaruh terhadap kinerja perusahaan. Selain itu, pengujian menunjukkan bahwa inovasi radikal tidak berpengaruh pada kinerja perusahaan. Oleh karena itu, inovasi tambahan adalah cara terbaik yang dapat dipilih oleh UKM sebagai pendekatan TQM untuk mempengaruhi kinerja perusahaan. Penelitian ini dapat berkontribusi untuk usaha kecil dan menengah dalam pemilihan inovasi dalam praktik TQM. Hal ini akan membantu pengusaha mendapatkan kinerja perusahaan yang lebih baik
\end{abstract}

Kata kunci: manajemen kualitas total; inovasi tambahan; inovasi radikal; kinerja perusahaan; UKM 


\section{INTRODUCTION}

In this era of competition, Total Quality Management is one of the most influential forces for business continuity. [1], [2] have proved empirically that TQM improves company performance. Quality management is not only influential on large scale companies but also very influential on SMEs. In a previous study on TQM, it was concluded that TQM had a positive impact on company performance. If TQM is splendid, the company's performance will boost [3], [4], [5], [6], [7], [8], [9], [10], [11]. In addition to Total Quality Management, there is another factor that influences, that is innovation. As stated in [12], [13], to be able to shine in competition, innovation is important where many companies benefit from innovations made within a certain timeframe, but one should note that an organization's business will not succeed with its innovation if the product is produced not meeting consumer demand standards.

In the competition of strategy, innovation must be clear and precise according to consumer demand and expectation [14]. Total Quality Management faces the option of radically or incrementally innovating, especially in the SMEs sector with usually limited resources. Previous research does not detailed separated performance of incremental innovation and radical innovation. Incremental innovation is often interpreted only as a consequence of TQM. Therefore, the lack of clarity of the innovation needed to make significant changes especially in TQM which is said to have a positive effect on organizational performance [15].

Many previous researchers [16], [14], concluded that the relationship between TQM and competitive advantage in business organizations, mediated by innovation, for future researchers, is an important problem. The results of the study [17], [12], concluded that there was a new archetype for international competitiveness, which was dynamic and based on innovation
In business organizations, it results from a competitive advantage derived from the capacity of innovation and total quality management itself. This article is intended to help SMEs scale business organizations to improve organizational performance so they can compete and achieve success by improving TQM through innovation with appropriate types and forms.

SMEs is very influential for the economic development of a region and even the nation, many factors determine the SMEs in developed or developing countries, and according to [18], [19], advanced SMEs is determined by a number of factors and criteria, such as location, size, age, structure, organization, number of employees, sales volume, asset value, ownership through innovation and technology. In 2019, in Indonesia there was a decline in food and beverage performance in small and medium industries, caused by many factors. Among other things, exchange rate fluctuations that affect the price of raw materials. This does not apply to large scale companies because they use previous price agreements [20]. Business competition, which becomes more competitive requires companies to implement the right business strategy in the business environment, is indicated by a continuous process of innovation and the high rate of changes in consumer taste [21]. SMEs also have to have a good Firm Performance, according to [22] in today's sharp business competition, companies are constantly looking for strategies to improve company performance and gain competitive advantage. In this case seen there are some relationship between TQM and Firm performance where there are two approaches TQM that is, incremental innovation and radical innovation. Next is an explanation of the relationship of each variable to ensure the reliability and validity of the relationship between TQM, incremental innovation, radical innovation, and firm performance.

TQM and Incremental Innovation. Renewing or improving TQM in various SMEs business sectors can create innovations incrementally 
meaning that innovation will emerge or be introduced gradually. Experimental research conducted by [23] shows that TQM has a significant and positive impact on innovation performance. Innovations in high-tech companies are often faster and the content of innovation performance in this study includes the performance of radical innovations.

H1: Total Quality Management has an influence on the Incremental Innovation

TQM and Radical Innovation. TQM can affect the quality of service which resulted in customer satisfaction in itself. By Approaching radical innovations, there will likely influence the improvement of the efficiency and effectiveness of the organization, thereby improving the quality of performance and improving the organization's level of competitiveness. Studies conducted by [24] and [25] in Japanese manufacturing companies indicate that TQM has a positive influence on radical innovation approach hence increasingly reinforce the hypothesis proposed.

$\mathrm{H} 2$ : Total Quality Management has an influence on Radical Innovation

Incremental Innovation and Firm Performance Incremental innovation approach has a considerable role both to firm performance. Apabila uses an incremental innovation approach, then firm performance has plenty of time to adjust to changes in innovation in SMEs activities. [26] argue that effective product design will reduce costs by eliminating non value-added parts, making product creation easier, and this can be used in the SMEs sector.

H3: Incremental Innovation has an influence on Firm Performance

Radical Innovation and Firm Performance. More radical approach to innovation and change takes a short time innovation massive that is very influential on firm performance. If unpreparedness will occur, this innovation will make the company's performance worse which can lead to poor service to consumerism. Conversely, if the innovation is done optimally, it will produce good corporate performance. Provide a strong background where more radical innovations can be successfully implemented [27].

H4: Radical Innovation has an influence on Firm Performance

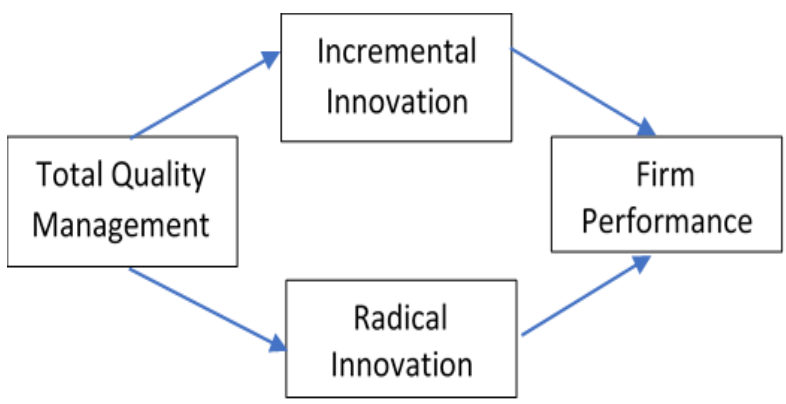

Figure 1 Conceptual Framework

\section{METHODOLOGY}

This research focuses on the small and medium scale food and beverage industry registered with the Indonesian Food and Beverage Entrepreneurs Association - GAPMMI. Based on the directory members of GAPPMI, GAPPMI members number 410 companies spread throughout Indonesia. Samples are taken based on the classification of small and medium-sized companies and are located in Jabodetabek. Data was taken by convenience sampling, the questionnaire was distributed to 130 companies, but there were 108 eligible samples.

The questionnaire was distributed in several ways, there were several companies visited directly, but there were several companies who wanted to fill out questionnaires through google form.

\section{RESULTS AND DISCUSSION}

Data is focused on small and medium enterprises with CEO positions percentage of $34,25 \%$ (37 respondents), with manager 
position $31,48 \%$ (34 respondents), and the other answer is $36.111 \%$ (39 respondents). Type of business in the field of fashion amounted to $28.703 \%$ (31 respondents), food and beverage business of $35.185 \% \quad(38$ respondents), and the other answered $36.111 \%$ (39 respondents). Operating time, less than one year equal to $47.22 \%$ (51 respondents), who answered 2-3 years 28,703\% (31 respondents), and who answered 3 years more by $24.074 \%$ (26 respondents). This data proves that the general background of different respondents in order to clarify that the data does not have any degree of doubt on this research. This data sample is taken from 108 different SMEs and processed through AMOS.

Validity and Reliability. Variable measurements have been measured by previous measurements. Firm Performance and TQM scales are taken from [28] literature. Radical Innovation and Incremental Innovation is derived from [29] and [30]. Measuring scale 1-5, with 1 means strongly disagree and 5 means strongly agree. Test validity and reliability to improve academic clarity and entrepreneurship.

Table 1. Reliability Test

\begin{tabular}{ccc}
\hline Variable & Items & $\begin{array}{c}\text { Cronbach's } \\
\text { Alpha }\end{array}$ \\
\hline $\begin{array}{c}\text { Total quality } \\
\text { management }\end{array}$ & 4 & 0.8251 \\
Firm performance & 5 & 0.8579 \\
Incremental performance & 3 & 0.8260 \\
Radical performance & 3 & 08292 \\
\hline
\end{tabular}

With Cronbach's Alpha results all $>0.6$ then all indicators from $1-15$ are reliable (consistent).

Table 2. Validity Test

\begin{tabular}{llc}
\hline Variable & \multicolumn{1}{c}{ Item } & r \\
\hline TQM & $\begin{array}{l}\text { Product Design cross- } \\
\text { functional }\end{array}$ & 0745 \\
& $\begin{array}{l}\text { quality management } \\
\text { process }\end{array}$ & 0818 \\
& $\begin{array}{l}\text { Empowerment of quality } \\
\text { Employee training }\end{array}$ & 0844 \\
& 0830
\end{tabular}

\begin{tabular}{llc}
\hline Variable & \multicolumn{1}{c}{ Item } & r \\
\hline II & $\begin{array}{l}\text { engine modification } \\
\text { gradually } \\
\text { modification gradual } \\
\text { process }\end{array}$ & 0838 \\
& $\begin{array}{l}\text { modification of information } \\
\text { technology gradually }\end{array}$ & 0860 \\
& engine modifications & 0882 \\
RI & radical & \\
& $\begin{array}{l}\text { modified radical process } \\
\text { modification of information }\end{array}$ & 0867 \\
& technology radically & 0847 \\
FP & $\begin{array}{l}\text { quality information } \\
\text { Performance Design }\end{array}$ & 0791 \\
& process quality & 0807 \\
& product quality & 0791 \\
& customer Satisfaction & 0745
\end{tabular}

With all sig 0 and $r>0.05$, are entirely valid (measure what you want measured). Thus, no indicator is dropped (omitted). The result is the result of reliability testing using SPSS with $\mathrm{N}$ of Cases 108 and $\mathrm{N}$ of its items 15.

Here is the result of data processing that has been done using AMOS software. In the SEM model, the Goodness of fit model can use many approaches.

Table 3. Goodness of Fit

\begin{tabular}{|c|c|c|c|}
\hline $\begin{array}{l}\text { Goodness } \\
\text { of fit index }\end{array}$ & $\begin{array}{l}\text { Results } \\
\text { Calculatio } \\
\mathrm{n}\end{array}$ & $\begin{array}{l}\text { Criteria } \\
\text { (cut-off } \\
\text { value) }\end{array}$ & $\begin{array}{l}\text { Conclusio } \\
\mathrm{n}\end{array}$ \\
\hline $\begin{array}{l}\mathrm{X}^{2}(\mathrm{Chi}- \\
\text { square })\end{array}$ & 197.964 & $\begin{array}{l}\text { Expecte } \\
\text { d Small }\end{array}$ & $\begin{array}{l}\text { Not } \\
\text { goodness } \\
\text { of fit }\end{array}$ \\
\hline $\begin{array}{l}\text { Significanc } \\
\text { e } \\
\text { probability }\end{array}$ & 0.000 & $\geq 0.05$ & $\begin{array}{l}\text { Not } \\
\text { goodness } \\
\text { of fit }\end{array}$ \\
\hline RMSEA & 0109 & $\leq 0.10$ & $\begin{array}{l}\text { Not } \\
\text { goodness } \\
\text { of fit }\end{array}$ \\
\hline NFI & 0782 & $\geq 0.90$ & $\begin{array}{l}\text { Marginal } \\
\text { fit }\end{array}$ \\
\hline RFI & 0.696 & $\geq 0.90$ & $\begin{array}{l}\text { Marginal } \\
\text { fit }\end{array}$ \\
\hline TLI & 0.802 & $\geq 0.90$ & $\begin{array}{l}\text { Marginal } \\
\text { fit }\end{array}$ \\
\hline CFI & 0.858 & $\geq 0.90$ & $\begin{array}{l}\text { Marginal } \\
\text { fit }\end{array}$ \\
\hline
\end{tabular}


From the results of the above table, it can be concluded that with various approaches used to produce conclusions of the resulting model is not goodness of fit but marginal fit.

Table 4. Hypothesis Testing

\begin{tabular}{|c|c|c|c|c|c|}
\hline & \multirow[t]{2}{*}{ Hypothesis } & \multicolumn{2}{|c|}{$\begin{array}{l}\text { Path } \\
\text { coefficient }\end{array}$} & \multirow{2}{*}{\multicolumn{2}{|c|}{$\begin{array}{l}\text { p-value } \\
\text { Decision }\end{array}$}} \\
\hline & & $\beta$ & SE & & \\
\hline $\begin{array}{l}\mathrm{H} 1: \mathrm{TQM} \\
\rightarrow \mathrm{II}\end{array}$ & $\begin{array}{l}\text { TQM has a } \\
\text { positive } \\
\text { influence } \\
\text { on the II }\end{array}$ & $\begin{array}{l}0.820 \\
*\end{array}$ & 0148 & 0000 & Acc \\
\hline $\begin{array}{l}\text { H2: } \\
\text { TQM } \rightarrow \\
\text { RI }\end{array}$ & $\begin{array}{l}\text { TQM have } \\
\text { positive } \\
\text { influence } \\
\text { on the RI }\end{array}$ & $\begin{array}{l}0.589 \\
*\end{array}$ & 0152 & 0.000 & Acce \\
\hline $\begin{array}{l}\mathrm{H} 3: \text { II } \\
\rightarrow \mathrm{FP}\end{array}$ & $\begin{array}{l}\text { II had a } \\
\text { positive } \\
\text { influence } \\
\text { on FP }\end{array}$ & $\begin{array}{l}0.490 \\
*\end{array}$ & 0.106 & 0.000 & Acce \\
\hline $\begin{array}{l}\mathrm{H} 4: \mathrm{RI} \\
\rightarrow \mathrm{FP}\end{array}$ & $\begin{array}{l}\text { RI has a } \\
\text { positive } \\
\text { influence } \\
\text { on FP }\end{array}$ & $\begin{array}{l}0, \\
137 *\end{array}$ & 0.081 & 0.093 & Reje \\
\hline
\end{tabular}

Hypothesis test shows that $\mathrm{H} 1, \mathrm{H} 2, \mathrm{H} 3$ has $\mathrm{p}$ value $<0.05$. this indicates that the hypothesis is accepted, meaning that there is an influence between TQM and Incremental Innovation in this study and proved true. Then there is the influence of TQM and Radical Innovation, and shows that Incremental Innovation has a relationship with Firm Performance. However, Radical Innovation has no effect on Firm Performance. $\mathrm{H} 4$ is rejected because it has a value of $0.093>0.05$. Thus, a suitable process of innovation to apply to SMEs is Infrastructure approach a gradual incremental Innovation.

With these data, it can be concluded that Incremental Innovation is a partial mediator between TQM and Firm Performance. So, Incremental Innovation becomes a better decision approach than Radical Innovation, according to the results of calculations that have been done

\section{CONCLUSION}

This study was conducted through the collection of primary data taken from various sectors of SMEs with the aim to know the relationship between TQM, Incremental Innovation, Radical Innovation, and Firm Performance. The research provides a new insight into the impact of TQM on Firm Ferformance through the process of Incremental Innovation or Radical Innovation. in addition, to find out what is the most appropriate way to determine what kind of Innovation will affect Firm Performance. The TQM approach can be taken by SMEs entrepreneurs and managers to make Firm Performance higher in the operating process of the business itself. This study gives a wish to contribute to theoretical development in several ways. As reported in the literature review section, empirical evidence supports the relationship between TQM and FP.

The proposed research model allows researchers to examine the impact of TQM as a complete body, including on two types of innovation performance as a competitive advantage. The proposed research model also allows researchers to examine the role of mediation from two types of innovation performance. The role of incremental innovation performance mediation will help to explain the importance of incremental innovation performance (emphasized by TQM) on competitive advantage.

Technology can improve the competitiveness of companies but the limitations of technology in SMEs become a certain challenge for the company [31]. Compared to large organizations, SMEs have a flat organizational structure with a lack of bureaucracy and this has a positive impact on flexibility, adaptability and speed in responding to changing TQM environments [32] and building a supportive culture [4]. In addition, 
the relationship between quality management practices, entrepreneurial strategies and performance can change and evolve over time, especially when regulation is a dynamic that involves a broad set of behavioral, organizational and environmental factors that may all affect relationships [33].

The results of this study conclude that Incremental Innovation is suitable for SMEs development process in various sectors. This is in accordance with the results of the data above which shows incremental innovation has a value of $p<0.05$. Compared to radical innovations that have a value of $p>0.05$. So it can be concluded that the selection of a suitable innovation process for the SMEs sector is Incremental Innovation.

Although the contribution is important, the results of this study should also be seen in the limitations of the studies. The focus of this research is based only on samples from SMEs. This research study can be expanded by using other samples as respondents, such as the larger industrial sector of the business form. It is clear that this work can be done on a larger scale in the future to generalize to a wider population in terms of increasing the number of case studies, sectors and also extending reach to various countries. For the next research

Suggestions for further research are found in the article [28], which discusses in more detail the object of innovation which is divided into two, namely products and processes. Subsequently, the future research can compare which objects of innovation should be selected, between Product Innovation or Process Innovation, so that it can give effect to Firm Performance better or improve.

\section{REFERENCES}

[1] Hendricks, K.B. and Singhal, V.R. (1997), "Does implementing an effective TQM program actually improve operating performance? Empirical evidence from firms that have won quality awards", Management Science, Vol. 43 No. 9, pp. 1258-74.Al-Dhaafri, H.S., Al-Swidi, A.K. and Yusoff, R.Z.B. (2016), "The mediating role of total quality management between the entrepreneurial orientation and the organizational performance", The TQM Journal, Vol. 28 No. 1, pp. 1754-2731.

[2] Vimal Kumar, R.R.K. Sharma, (2018) "Leadership styles and their relationship with TQM focus for Indian firms: An empirical investigation", International Journal of Productivity and Performance Management, Vol. 67 Issue: 6, pp.10631088, https://doi.org/10.1108/IJPPM-032017-0071

[3] Gandhy, Abel. (2018), Analysis of Service Quality And Customer Satisfaction Of Dunkin Donuts Stores in Gading Serpong, Jurnal Manajemen Industri dan Logistik, Vol. 2 No. 2, November 2018, DOI : 10.30998/jmil.v2i1.81

[4] Al-Dhaafri, H.S., Al-Swidi, A.K. and Yusoff, R.Z.B. (2016), "The mediating role of total quality management between the entrepreneurial orientation and the organizational performance", The TQM Journal, Vol. 28 No. 1, pp. 1754-2731.

[5] Bou, J.C. and Beltrán, I. (2005), “Total quality management, high-commitment human resource strategy and firm performance: an empirical study", Total Quality Management \& Business Excellence, Vol. 16 No. 1, pp. 71-86.

[6] Curkovic, S., Vickery, S. and Dröge, C. (2000), "Quality-related action programs: their impact on quality performance and firm performance", Decision Sciences, Vol. 31 No. 4, pp. 885-902

[7] Konecny, P. and Thun, J.-H. (2011), "Do it separately or simultaneously - an empirical analysis of a conjoint implementation of TQM and TPM on plant performance", International Journal of Production Economics, Vol. 133 No. 2, pp. 496-507. 
[8] Prajogo, D.I. and Hong, S.W. (2008), "The effect of TQM on performance in $R \& D$ environments: a perspective from South Korean firms", Technovation, Vol. 28 No. 12 , pp. 855-863.

[9] Reed, R., Lemak, D.J. and Montgomery, J.C. (1996), "Beyond process: TQM content and firm performance", The Academy of Management Review, Vol. 21 No. 1, pp. 173-202.

[10] Sadikoglu, E. and Zehir, C. (2010), "Investigating the effects of innovation and employee performance on the relationship between total quality management practices and firm performance: an empirical study of Turkish firms", International Journal of Production Economics, Vol. 127 No. 1, pp. 13-26.

[11] Samson, D. and Terziovski, M. (1999), "The relationship between total quality management practices and operational performance", Journal of Operations Management, Vol. 17 No. 4, pp. 393-409.

[12] Farhana Ferdousi, Kevin Baird, Rahat Munir, Sophia Su, (2018) "Associations between organisational factors, TQM and competitive advantage: Evidence from an emerging economy", Benchmarking: An International Journal, Vol. 25 Issue: 3, pp.854-873, https://doi.org/10.1108/BIJ05-2017-0110

[13] Daghfous, A. (2004), “Absorptive capacity and the implementation of knowledgeintensive best practices", SAM Advanced Management Journal, Vol. 69 No. 2, p. 21

[14] Kanwal Nasim, (2018) "Role of internal and external organizational factors in TQM implementation: A systematic literature review and theoretical framework", International Journal of Quality \& Reliability Management, Vol. 35 Issue: 5, pp.10141033, https://doi.org/10.1108/IJQRM-102016-0180
[15] Kenneth W. Green, R. Anthony Inman, Victor E. Sower, Pamela J. Zelbst, (2018) "Impact of JIT, TQM and green supply chain practices on environmental sustainability", Journal of Manufacturing Technology Management, https://doi.org/10.1108/JMTM-01-2018$\underline{0015}$

[16] Ismail Sila, (2018) "Country and sector effects on the relationships among TQM practices and key performance measures", International Journal of Productivity and Performance Management, https://doi.org/10.1108/IJPPM-11-2017$\underline{0297}$

[17] Porter, M.E. and Van der Linde, C. (1995), "Toward a new conception of the environment competitiveness relationship", The Journal of Economic Perspectives, Vol. 9 No. 4, pp. 97-118.

[18]Rahman, S.-U. (2001a), “A comparative study of TQM practice and organizational performance of SMEs with and without ISO 9000 certification", International Journal of Quality \& Reliability Management, Vol. 18 No. 1, pp. 35-49.

[19] Rahman, S.-U. (2001b), "Total quality management practices and business outcome: evidence from small and medium enterprises in Western Australia", Total Quality Management, Vol. 12 No. 2, pp. 201-210.

[20] https://katadata.co.id/berita/2019/05/09/per tumbuhan-industri-makanan-minumantertekan-penurunan-harga-sawit

[21] Masnita, Yolanda., Triyowati, Hermien., and Rasyawal, Mangku. (2017), "Supply Chain Practices Impact on Supplier Performance: The Mediating Role of Market-Based and Operational Performance", International Journal of Applied Business and Economic Research, Vol. 15 No.8, pp. 209-221. 
[22]Atuahene-Gima, K. and Ko, A. (2001), “An empirical investigation of the effect of the market orientation and entrepreneurship orientation alignment on product innovation", Organization Science, Vol. 12 No. 1, pp. 54-74.

[23] Hung, R.Y.Y., Lien, B.Y.H., Yang, B., Wu, C.M. and Kuo, Y.M. (2011), "Impact of TQM and organizational learning on innovation performance in the high-tech industry", International Business Review, Vol. 20 No. 2, pp. 213-225.

[24] Matsui, Y. (2002), “An empirical analysis of quality management in Japanese manufacturing companies", DecisionMaking at the Speed of Light: What is Amiss, Action Management Associates, pp. $1-18$.

[25] Phan, A.C., Abdallah, A.B. and Matsui, Y. (2011), "Quality management practices and competitive performance: empirical evidence from Japanese manufacturing companies", International Journal of Production Economics, Vol. 133 No. 2, pp. 518-529.

[26] Richard, R., David, J.L. and Neal, P.M. (2000), "Total quality management and sustainable competitive advantage", Journal of Quality Management, Vol. 5 No. 1, pp. 5-26.

[27] Jha, S., Noori, H. and Michela, J.L. (1996), "The dynamics of continuous improvement: aligning organizational attributes and activities for quality and productivity", The International Journal of Quality Science, Vol. 1 No. 1, p. 19.

[28] Saumyaranjan Sahoo and Sudhir Yadav (2017), "Entrepreneurial orientation of SMEs, total quality management and firm performance", Journal of Manufacturing Technology Management, Vol. 28 Issue: 7, pp.892-912.
[29] Van Cang Nguyen and Ngoc Tuan Chau (2017), "Research framework for the impact of total quality management on competitive advantage: The mediating role of innovation performance", Review of International Business and Strategy, Vol. 27 Issue: 3, pp.335-351.

[30] Konecny, P. and Thun, J.-H. (2011), "Do it separately or simultaneously - an empirical analysis of a conjoint implementation of TQM and TPM on plant performance", International Journal of Production Economics, Vol. 133 No. 2, pp. 496-507

[31] Masnita, Yolanda., Triyowati, Hermien., and Rasyawal, Mangku. (2018), "Urban community empowerment: context on supply chain collaboration in the SMEs", The 4th International Seminar on Sustainable Urban Development - IOP Conf. Series: Earth and Environmental Science 106 pp.1-6.

[32] Majumdar, J.P. and Manohar, B.M. (2016), "Why Indian manufacturing SMEs are still reluctant in adopting total quality management", International Journal of Productivity and Quality Management, Vol. 17 No. 1, pp. 16-35

[33] Yunis, M., Jung, J. and Chen, S. (2012), "TQM, strategy and performance: a firm level analysis", International Journal of Quality \& Reliability Management, Vol. 30 No. 6, pp. 690-714.

\section{Biografi Penulis}

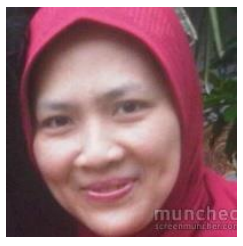

Yolanda Masnita is senior researcher and lecturer at Trisakti University, Indonesia since 1990. Scopus ID: 57200245927. ORCID ID: https://orcid.org/0000-0002-5758-8146.

Google Scholar: https://scholar.google.com /citations ?user= lQgrbNIAAAAJ\&hl=en. 
Her current research mostly interests with supply chain, marketing digitalization, and Islamic management. She completed her doctoral program in 2011 at the University of Indonesia with the title of her dissertation: The Influence of Locus Attribution on Service Recovery: A Theory of Resource Exchange Approach.

For 5 years continuously, she received research grants from the Indonesian Ministry of Research and Technology. Currently active in writing books, writing business topics in national-scale newspapers, and being an editor in several Indonesian national journals 